\title{
Preparation of $\mathrm{RhOx} / \mathrm{Ce}_{\mathrm{y}} \mathrm{Pr}_{1-\mathrm{y}} \mathrm{O}_{2} \mathrm{~N}_{2} \mathrm{O}$ decomposition catalysts by rhodium nitrate impregnation with different solvents.
}

\author{
V. Rico-Pérez, C. Salinas-Martínez de Lecea, A. Bueno-López*. \\ Inorganic Chemistry Department. University of Alicante. Ap. 99 E03080. \\ Alicante (Spain)
}

\begin{abstract}
The effect of the solvent (water, ethanol or acetone) used to impregnate $\mathrm{Ce}_{y} \mathrm{Pr}_{1}$ ${ }_{y} \mathrm{O}_{2}(\mathrm{y}=1,0.9$ or 0.5$)$ supports with rhodium nitrate, in order to prepare $\mathrm{N}_{2} \mathrm{O}$ decomposition catalysts, has been studied. $\mathrm{RhOx} / \mathrm{Ce}_{\mathrm{y}} \mathrm{Pr}_{1-\mathrm{y}} \mathrm{O}_{2}$ catalysts were prepared and characterized by $\mathrm{N}_{2}$ adsorption at $-196{ }^{\circ} \mathrm{C}$, XRD, Raman spectroscopy, TEM, XPS and $\mathrm{H}_{2}$-TPR. The activity for $\mathrm{N}_{2} \mathrm{O}$ decomposition of the catalysts studied was related with the RhOx-support interaction, and both the nature of the ceria support and of the solvent used for rhodium impregnation affected such interaction. Ceria doping with $10 \%$ praseodymium had a positive effect in the RhOx-support interaction, but the benefit on the catalytic activity was only obtained for water impregnation because the temperature peaks created during calcination of ethanol and acetone-impregnated catalysts promoted $\mathrm{Ce}_{0.9} \mathrm{Pr}_{0.1} \mathrm{O}_{2}$ and $\mathrm{RhOx}$ sintering. The interaction between $\mathrm{RhOx}$ and $\mathrm{Ce}_{0.5} \mathrm{Pr}_{0.5} \mathrm{O}_{2}$ was not as good as that with $\mathrm{Ce}_{0.9} \mathrm{Pr}_{0.1} \mathrm{O}_{2}$. The best catalyst was obtained by impregnating $\mathrm{Ce}_{0.9} \mathrm{Pr}_{0.1} \mathrm{O}_{2}$ with a water solution of rhodium. However, if acetone or ethanol must be used for any reason the pure ceria support is more suitable (under the calcination conditions of this study; 250 to $500^{\circ} \mathrm{C}$ at $10^{\circ} \mathrm{C} / \mathrm{min}$ ) because do not sinters during solvents combustion.
\end{abstract}

Key words: Ceria catalyst; Rhodium catalyst; $\mathrm{N}_{2} \mathrm{O}$ decomposition; metalsupport interaction 
1. Introduction.

Ceria-based materials are of interest in catalysis because of their oxygen storage capacity (OSC) and lattice oxygen mobility [1-3]. These properties are dependent of the crystal size and defects, and can be modified by ceria doping. Ceria-based oxides also affect the catalytic behavior of supported metals [4]. In this sense, RhOx supported on praseodymium-doped ceria has showed enhanced $\mathrm{N}_{2} \mathrm{O}$ decomposition activity with regard to $\mathrm{RhOx}$ catalyst with pure ceria support [5]. Praseodymium doping modifies the properties of the ceria lattice oxygen, lowers metal-oxygen binding energy in the Rh-mixed oxide interface and increases the number of defects (oxygen vacancies) [6].

In previous studies [7, 8], the calcination conditions were modified in order to improve the distribution of rhodium and to enlarge the rhodium-ceria 47 interface of $\mathrm{RhO}_{x} / \mathrm{CeO}_{2}$ catalysts. Improved catalytic activity for $\mathrm{N}_{2} \mathrm{O}$ decomposition and $\mathrm{CO}$ oxidation was obtained by flash calcination, which consisted of introducing the ceria support-impregnated rhodium precursor in a furnace which was pre-heated at $250 \stackrel{\circ}{ } \mathrm{C}$. The solvent used for rhodium 51 precursor impregnation was water, as usually, and the speed at which water 52 evaporates from the ceria-based support seemed very important for the catalyst 53 properties, because it affected the size of the $\mathrm{RhO}_{x}$ particles on the final catalyst $54[7,8]$. This lead us to look for different procedures to accelerate the evaporation 55 of the rhodium precursor solvent, and one of the options was to change water 56 by some other more volatile solvent. 
58 only potentially affects the distribution of the impregnated metal precursor, due 59 to the evaporation rate, but could also had some other important roles. The optimum conditions for a successful infiltration of the support pores mainly 61 depend on the surface polarity, the density and polarity of the solvent, and the 62 solubility of the precursor in the solvent. For a surface with a high density of 63 polar functional groups a polar solvent will be suitable to obtain proper 64 wettability and suitable diffusion through the pores [9]. The density and polarity 65 of the solvent must be also taken into account in the impregnation of 66 honeycomb monoliths, because the solution must enter into the channels [10, 67 11].

As far as we know, the effect of the solvent used to impregnate praseodymium doped ceria supports with a rhodium salt on the properties of the obtained catalysts has not been reported, and the goal of the current study is to

71 compare three solvents (water, ethanol and acetone) for such purpose.

\section{Experimental}

\subsection{Catalyst preparation}

Nine catalysts, labeled as $\mathrm{RhO}_{x}($ solvent $) / \mathrm{Ce}_{\mathrm{y}} \mathrm{Pr}_{1-\mathrm{y}} \mathrm{O}_{2}$, were prepared. The solvent could be water, ethanol or acetone and $y$ takes values of $1,0.9$ or 0.5 .

77 Cerium and praseodymium nitrate precursors $\left(\mathrm{Ce}\left(\mathrm{NO}_{3}\right)_{3} \cdot 6 \mathrm{H}_{2} \mathrm{O}\right.$ (Aldrich, 99.99 78 wt.\%) and $\left(\operatorname{Pr}\left(\mathrm{NO}_{3}\right)_{3} \cdot 6 \mathrm{H}_{2} \mathrm{O}\right.$ (Aldrich, 99.9 wt.\%)) were mixed in an agate mortar 79 to obtain $\mathrm{CeO}_{2}, \mathrm{Ce}_{0.9} \mathrm{Pr}_{0.1} \mathrm{O}_{2}$ and $\mathrm{Ce}_{0.5} \mathrm{Pr}_{0.5} \mathrm{O}_{2}$ after calcination at $600 \stackrel{\circ}{\circ} \mathrm{C}$ for 90 
$80 \mathrm{~min}$ (heating rate $10^{\circ} \mathrm{C} / \mathrm{min}$ ). Rhodium was loaded on these oxides by incipient 81 wetness impregnation with the proper amount of $\mathrm{Rh}\left(\mathrm{NO}_{3}\right)_{3} \cdot \mathrm{xH}_{2} \mathrm{O}$ (Sigma82 Aldrich, $\sim 36 \mathrm{wt} . \%$ as $\mathrm{Rh}$ ) dissolved in water, ethanol or acetone in order to

83 obtain 1 wt.\% rhodium in the final catalysts. The catalysts were calcined in 84 flash conditions, that is, the impregnated supports were introduced in a muffle 85 furnace that was pre-heated at $250^{\circ} \mathrm{C}$, and then the temperature was increased 86 at $10 \stackrel{\circ}{\circ} / \min$ up to $500{ }^{\circ} \mathrm{C}$ (the maximum temperature was maintained for 30 $87 \min )$.

Additionally, three portions of pure ceria were impregnated with rhodium 89 nitrate solutions using water, ethanol and acetone, respectively, and were 90 placed in test tubes with a thermocouple located inside the solids. The tubes 91 were introduced in a vertical furnace that was previously heated at $250{ }^{\circ} \mathrm{C}$, and 92 the temperature was registered as a function of time.

\subsection{Catalysts characterization}

X-ray diffractograms were recorded in a Bruker D8-advance

diffractometer, using CuKa radiation $(\lambda=1.540598 \AA)$. Diffractograms were recorded between $10^{\circ}$ and $80^{\circ}(2 \theta)$ with steps of $0.02^{\circ}$ and a step time of 3 sec.

97 The average crystal size (D) was determined using the Williamson-Hall's 98 equation.

Raman spectra were recorded in a Jobin Yvon Horiba Raman dispersive 100 spectrometer with a variable-power He-Ne laser source (632.8 nm), $0.9 \mathrm{~mW}$ of 101 power, a confocal microscope with a 10x objective of long focal length and a diffraction grating of 600 lines $/ \mathrm{mm}$. The spectrum of each sample was obtained 
103 using 2 scans with an acquisition time for each individual spectrum of 200 104 seconds.

X-ray photoelectron spectroscopy (XPS, K-ALPHA, Thermo Scientific) was used to analyze the catalysts surface. The powder catalysts were supported on a double-sided carbon tape and were analyzed without previous pretreatment. The spectra were collected using Al-Ka radiation $(1486.6 \mathrm{eV})$, monochromatized by a twin crystal monochromator, yielding a focused X-ray 110 spot with a diameter of $400 \mu \mathrm{m}$, at $3 \mathrm{~mA} \times 12 \mathrm{kV}$. The alpha hemispherical 111 analyzer was operated in the constant energy mode and pass energy of $50 \mathrm{eV}$. 112 Charge compensation was achieved with the system flood gun that provides 113 low energy electrons and low energy argon ions from a single source. Carbon 114 concentration on the catalysts surface amounts to $30-40 \%$ in all cases, and the 115 binding energy (BE) and kinetic energy (KE) scales were adjusted by setting the 116 C1s transition at $284.6 \mathrm{eV}$.

Experiments of temperature programmed reduction with $\mathrm{H}_{2}\left(\mathrm{H}_{2}\right.$-TPR) 118 were carried out in a Micromeritics Pulse ChemiSorb 2705 device, consisting of 119 a tubular quartz reactor (inner diameter $5 \mathrm{~mm}$ ) coupled to a TCD analyzer. A 120 cold trap was placed before the TCD, consisting of a mixture of isopropyl 121 alcohol and liquid nitrogen (temperature $-89{ }^{\circ} \mathrm{C}$ ). The experiments were 122 conducted with $20 \mathrm{mg}$ of fresh catalyst at a ramp rate of $10 \stackrel{\circ}{\circ} \mathrm{C} / \mathrm{min}$ from room 123 temperature to $1050 \stackrel{\circ}{\circ} \mathrm{C}$ in $40 \mathrm{ml} /$ min flow of $5 \mathrm{vol} \% \mathrm{H}_{2}$ in $\mathrm{Ar}$. ${ }^{\circ} \mathrm{C}$ in an automatic volumetric system (Autosorb-6, Quantachrome). Samples were outgassed at $150{ }^{\circ} \mathrm{C}$ for $4 \mathrm{~h}$ under vacuum before the $\mathrm{N}_{2}$ adsorption 
127 measurements. The BET surface areas were determined from the $\mathrm{N}_{2}$ 128 adsorption isotherms.

TEM characterization was performed using a JEOL (JEM-2010)

130 microscope, equipped with an EDS analyzer (OXFORD, model INCA Energy

131 TEM100). A few droplets of an ultrasonically dispersed suspension of the 132 catalyst in ethanol were placed in a copper grid with lacey carbon film and dried 133 at ambient conditions.

\section{3. $\mathrm{N}_{2} \mathrm{O}$ decomposition tests}

135

$\mathrm{N}_{2} \mathrm{O}$ decomposition tests were performed in a U-shaped fix-bed quartz

136

137

138

139

140

141

142

\section{3. Results and discussion.}

145 3.1. Catalysts temperature during rhodium nitrate thermal decomposition. The effect of the solvent used for rhodium precursor impregnation on the

147 temperature profile during the further calcination step was studied as described 
148 in section 2.1. The same experiment was performed with an empty test tube.

149 The temperature profiles registered are plotted in Figure 1.

150 The temperature profile of the empty test tube shows a sharp increase

151 during approximately 5 minutes followed by a smooth increase that reaches a 152 constant value of $220 \stackrel{\circ}{ } \mathrm{C}$ (slightly lower than the set-point temperature; $250 \stackrel{\circ}{ } \mathrm{C}$ )

153 after 10 minutes. The temperature profiles of the impregnated ceria samples are

154 different. The temperature of the sample impregnated with the water solution

155 increased until $100^{\circ} \mathrm{C}$, and reached a plateau at this temperature that can be

156 attributed to water evaporation. A second increase of temperature occurs

157 afterwards, reaching the same temperature than the empty tube in $15 \mathrm{~min}$. The

158 samples impregnated with the ethanol or acetone solutions also exhibit solvent

159 evaporation (boiling temperature $=78{ }^{\circ} \mathrm{C}$ and $56^{\circ} \mathrm{C}$ for ethanol and acetone,

160 respectively) but this period is much shorter than in water impregnation,

161 because a sharp increase of temperature is observed. The peak temperatures

162 reached are considerably higher than the furnace temperature. This behavior is

163 attributed to the exothermal combustion of the solvent. As it will be appealed for

164 several times throughout this article, the temperature increase occurred during

165 the thermal treatment affects the final features of the catalysts impregnated with 166 acetone or ethanol rhodium solutions.

167 3.2. $\mathrm{N}_{2} \mathrm{O}$ decomposition tests.

$\mathrm{N}_{2} \mathrm{O}$ decomposition tests were performed with the nine catalysts prepared, and the conversion curves obtained are compiled in Figure 2.

171 precursor impregnation affect the final activity of the catalysts. For pure ceria, 
172 the type of solvent has no effect on the catalysts behavior (Figure 2.a). The

173 three $\mathrm{RhO}_{x}$ (solvent) $/ \mathrm{CeO}_{2}$ catalysts decompose $\mathrm{N}_{2} \mathrm{O}$ from $200^{\circ} \mathrm{C}$ approximately

174 and achieve total decomposition at $375^{\circ} \mathrm{C}$ following the same decomposition

175 profile. On the contrary, the solvent used for rhodium precursor impregnation

176 strongly modifies the behavior of catalysts prepared with doped ceria supports

177 (Figures 2.b and 2.c). Regardless the molar fraction of praseodymium in doped

178 ceria, the best results were obtained with catalysts impregnated with the water

179 solution of rhodium nitrate. Both ethanol and acetone impregnations lead to a

180 significant decrease of the catalytic activity with regard to the counterpart

181 catalysts impregnated with water. The $\mathrm{N}_{2} \mathrm{O}$ decomposition curves obtained for

182 praseodymium-containing catalysts impregnated with acetone or ethanol

183 rhodium solution were delayed by $50-75^{\circ} \mathrm{C}$ with regard to the curves of the

184 catalysts impregnated with water. The effect of the solvent on the

185 physicochemical properties of the catalysts, and at the end on their catalytic

186 performance, is analyzed in detail in the coming sections.

The temperatures required to decompose $50 \%$ of $\mathrm{N}_{2} \mathrm{O}\left(\mathrm{T}_{50}\right)$ in these 188 catalytic tests have been compiled in Table 1.

Comparing the $T_{50}$ values, it can be concluded that the impregnation with 190 ethanol or acetone rhodium solutions has a negative effect on catalysts 191 supported on doped ceria with regard to catalysts supported on pure ceria. 192 However, using water as the solvent, superior performance of $193 \mathrm{RhO}_{x}\left(\mathrm{H}_{2} \mathrm{O}\right) / \mathrm{Ce}_{0.9} \operatorname{Pr}_{0.1} \mathrm{O}_{2}$ is observed with regard to catalysts with pure and $50 \%$ 194 praseodymium doped ceria supports. The positive effect of $10 \%$ ceria doping 195 with praseodymium is in agreement with previous publications [6]. The $\mathrm{N}_{2} \mathrm{O}$ 
196 decomposition capacity of catalysts prepared by water impregnation of rhodium

197 follows the trend:

198

$$
\mathrm{RhO}_{x} / \mathrm{Ce}_{0.9} \mathrm{Pr}_{0.1} \mathrm{O}_{2}>\mathrm{RhO}_{x} / \mathrm{CeO}_{2} \approx \mathrm{RhO}_{x} / \mathrm{Ce}_{0.5} \mathrm{Pr}_{0.5} \mathrm{O}_{2}
$$

199

According to this trend, ceria doping with $10 \%$ praseodymium has a positive effect on the catalytic activity, as already observed [6], while $50 \%$ 201 praseodymium doping has no effect. As it will be discussed afterwards, the 202 amount of praseodymium not only affects ceria properties but also the $\mathrm{RhO}_{\mathrm{x}^{-}}$ 203 ceria interaction and this can explain the observed trend. For a future work, it 204 will be desirable to perform an optimization study of the praseodymium amount 205 on the $\mathrm{RhO}_{\mathrm{x}} / \mathrm{Ce}_{\mathrm{y}} \mathrm{Pr}_{1-\mathrm{y}} \mathrm{O}_{2}$ catalysts (by using water impregnation of rhodium 206 precursor), but this is out of the scope of the current study.

3.3. Catalysts characterization by $N_{2}$ adsorption at $-196{ }^{\circ} \mathrm{C}, \mathrm{XRD}$ and Raman 208 spectroscopy.

$\mathrm{N}_{2}$ adsorption at $-196 \stackrel{\circ}{\circ} \mathrm{C}, \mathrm{XRD}$ and Raman spectroscopy techniques 210 were used to analyze the physicochemical properties of the materials prepared. 211 These techniques provide (not only but mainly) information about the properties 212 of the ceria-based supports. The characterization results obtained are 213 presented in Table 2, including the BET surface area of the supports and 214 catalysts and the ceria supports crystal size and lattice parameters determined 215 by XRD.

The BET surface areas of all catalysts prepared with the un-doped ceria 217 support are almost equal $\left(56-60 \mathrm{~m}^{2} / \mathrm{g}\right)$, regardless the solvent used for rhodium 218 impregnation, and are also similar to that of the ceria support $\left(61 \mathrm{~m}^{2} / \mathrm{g}\right)$. In 
219 accordance with the BET values, the ceria crystal sizes and ceria lattice 220 parameters corresponding to these three catalysts are also similar to each 221 other. These results allow concluding that the nature of the solvent used for 222 rhodium impregnation do not affect the particle size/area of the pure ceria 223 support (both parameters are related to each other in this type of oxides [12]), 224 which is in agreement with the same catalytic activity obtained with the three 225 praseodymium-free catalysts (see Figure 2a).

The BET surface area of the $\mathrm{Ce}_{0.9} \mathrm{Pr}_{0.1} \mathrm{O}_{2}$ support is $50 \mathrm{~m}^{2} / \mathrm{g}$, which is 227 slightly lower than that of the pure ceria. The catalysts with $\mathrm{Ce}_{0.9} \mathrm{Pr}_{0.1} \mathrm{O}_{2}$ support 228 impregnated with ethanol or acetone solutions present a considerably lower 229 BET area $\left(31-33 \mathrm{~m}^{2} / \mathrm{g}\right)$ than the support, while the catalyst impregnated with the 230 water solution of rhodium $\left(\mathrm{RhO}_{x}\left(\mathrm{H}_{2} \mathrm{O}\right) / \mathrm{Ce}_{0.9} \mathrm{Pr}_{0.1} \mathrm{O}_{2}\right)$ keeps the same BET area 231 than the support $\left(50 \mathrm{~m}^{2} / \mathrm{g}\right)$. These results must be related to the $\mathrm{N}_{2} \mathrm{O}$ 232 decomposition results obtained with these three $\mathrm{Ce}_{0.9} \mathrm{Pr}_{0.1} \mathrm{O}_{2}$-supported 233 catalysts (see Figure 2.b), that is, the highest activity was obtained with the 234 water-impregnated catalyst (also with the highest BET surface area among 235 catalysts of this series) and the worse catalytic results were obtained with 236 ethanol/acetone-impregnated catalysts. As it was previously demonstrated (see 237 Figure 1), temperature gradients are created during the calcination of catalysts 238 impregnated with ethanol or acetone rhodium solutions while not with water. 239 These gradients created due to the exothermic combustion of the solvents favor $240 \mathrm{Ce}_{0.9} \mathrm{Pr}_{0.1} \mathrm{O}_{2}$ sintering and decrease the activity of the resulting catalysts. The 241 BET surface area of a $\mathrm{Ce}_{0.9} \mathrm{Pr}_{0.1} \mathrm{O}_{2}$ sample impregnated with acetone (but 242 without rhodium) and calcined under the same conditions than the catalysts was 
$24350 \mathrm{~m}^{2} / \mathrm{g}$ (the same than that of fresh $\mathrm{Ce}_{0.9} \mathrm{Pr}_{0.1} \mathrm{O}_{2}$ ). This evidences that rhodium 244 catalyzes the solvents combustion.

Finally, the BET area is low and very similar for all $\mathrm{Ce}_{0.5} \operatorname{Pr}_{0.5} \mathrm{O}_{2}$-containg catalysts $\left(17-20 \mathrm{~m}^{2} / \mathrm{g}\right)$, being also similar to that of the $\mathrm{Ce}_{0.5} \operatorname{Pr}_{0.5} \mathrm{O}_{2}$ support.

247 This means that rhodium impregnation and further calcination do not affects the 248 area of this $\mathrm{Ce}_{0.5} \mathrm{Pr}_{0.5} \mathrm{O}_{2}$ support, which is already much lower to that of $\mathrm{CeO}_{2}$ 249 synthesized in equal conditions $\left(61 \mathrm{~m}^{2} / \mathrm{g}\right)$. In this case, a relationship between 250 catalytic activity and catalyst sintering during calcination is not found, since the 251 BET areas of all $\mathrm{Ce}_{0.5} \operatorname{Pr}_{0.5} \mathrm{O}_{2}$-containg catalysts are similar while important 252 differences on activity were observed (see Figure 2c). As it will be demonstrated by XPS, TEM and $\mathrm{H}_{2}$-TPR characterization afterwards, the $\mathrm{RhO}_{\mathrm{x}}-\mathrm{Ce}_{\mathrm{y}} \mathrm{Pr}_{1-\mathrm{y}} \mathrm{O}_{2}$ 254 interaction also plays a key role on the activity of these catalysts, and the nature 255 of the solvent used for rhodium impregnation affects such interaction.

It is important to note that, among all catalysts prepared in this study, the 257 highest specific activity (calculated as $\mathrm{N}_{2} \mathrm{O}$ decomposition rate per $\mathrm{m}^{2}$ of 258 catalyst; these plots are not shown for the sake of brevity) corresponds to $259 \mathrm{RhO}_{x}\left(\mathrm{H}_{2} \mathrm{O}\right) / \mathrm{Ce}_{0.5} \mathrm{Pr}_{0.5} \mathrm{O}_{2}$. This suggests that it would be desirable to focus future 260 research to the preparation $\mathrm{Ce}_{0.5} \mathrm{Pr}_{0.5} \mathrm{O}_{2}$ supports with higher surface area.

As a summary, the BET surface area of $\mathrm{CeO}_{2}\left(61 \mathrm{~m}^{2} / \mathrm{g}\right)$ and $\mathrm{Ce}_{0.5} \operatorname{Pr}_{0.5} \mathrm{O}_{2}$ $262\left(18 \mathrm{~m}^{2} / \mathrm{g}\right)$ does not change significantly upon rhodium impregnation and 263 calcination, regardless the solvent used, while the area of $\mathrm{Ce}_{0.9} \mathrm{Pr}_{0.1} \mathrm{O}_{2}\left(50 \mathrm{~m}^{2} / \mathrm{g}\right)$ 264 drops (to $31-33 \mathrm{~m}^{2} / \mathrm{g}$ ) upon rhodium impregnation with ethanol or acetone 265 solutions and further calcination. On the contrary, there is no effect of rhodium 266 impregnation with the water solution on the surface area of $\mathrm{Ce}_{0.9} \mathrm{Pr}_{0.1} \mathrm{O}_{2}$. 
Additional information about the features of the ceria-based supports was obtained from XRD (Figure 3) and Raman spectroscopy (Figure 4). The X-ray diffractograms only contain the main reflections of a fluorite-structured material 270 with a face centered cubic unit cell, corresponding to the (111), (200), (220), 271 (311), (222) and (400) planes. Evidences of segregated phases are not obvious 272 in Figure 3. However, the presence of segregated $\mathrm{PrO}_{x}$ species is difficult to be 273 detected by $\mathrm{XRD}$, because the $\mathrm{XRD}$ patterns of such $\mathrm{PrO}_{\mathrm{x}}$ species are quite 274 similar to that of ceria [13]. Asymmetric XRD peaks could suggest the presence 275 of segregated $\mathrm{CeO}_{2}$-rich and $\mathrm{PrO}_{x}$-rich phases, but this is not the case of the 276 diffractograms in Figure 3.

The position and shape of the diffraction peaks is quite similar for all 278 catalysts. See, for instance, the zoom of the (111) peaks inset in Figure 3. As a 279 result, the lattice parameter of the ceria-based supports is also quite similar for 280 all catalysts (see data in Table 2). The expansion and contraction of the crystal 281 lattice is expected to occur due to ceria doping with large or small cations, 282 respectively [14]. However, the sizes of the $\mathrm{Ce}^{3+/ 4+}$ cations $(0.114 \mathrm{~nm} / 0.097 \mathrm{~nm})$ 283 are quite similar to those of the $\mathrm{Pr}^{3+/ 4+}$ cations $(0.113 \mathrm{~nm} / 0.096 \mathrm{~nm})$, and 284 therefore, the partial substitution of cerium by praseodymium cations has a 285 minor effect in the lattice constant of doped ceria. Slightly higher lattice 286 constant values were obtained with some doped ceria catalysts with regard to 287 values of catalysts with pure ceria. This must be attributed to the presence of 288 more +3 cations, which are larger than +4 cations, mainly $\mathrm{Pr}^{3+}$ because $\mathrm{Pr}^{4+}$ is 289 reduced more easily than $\mathrm{Ce}^{4+}[15,16]$. With regards to crystal sizes the data 290 are consistent with the changes observed in BET surface areas, as expected 291 [12]. 
Raman spectroscopy characterization is consistent with XRD conclusions and this technique also provides evidences of praseodymium incorporation into 294 the ceria framework. As a general behavior, four Raman bands are detected on 295 the spectra included in Figure 4, but all these four bands are not seen in all 296 spectra.

The band at $444-463 \mathrm{~cm}^{-1}$ is ascribed to the Raman active $F_{2 g}$ mode of 298 fluorite ceria $[17,18]$. This can be viewed as a symmetric breathing mode of the 299 oxide anions surrounding each cation. The intensity of this peak is highest for 300 catalysts with the pure ceria support (Figure 4a). A slight deformation of ceria structure can be elucidated due to the introduction of praseodymium into the 302 ceria structure (in agreement with the lattice parameter calculated by XRD, 303 Table 2). The presence of $\operatorname{Pr}^{3+}$ cations, which are bigger than $\mathrm{Ce}^{4+}$, affects the 304 oxygen breathing mode and the $F_{2 g}$ signal intensity. In addition, the 305 fluorescence produced by praseodymium also diminishes the intensity of the 306 main peak. The position of $\mathrm{F}_{2 \mathrm{~g}}$ peak shifts towards lower Raman shifts by 307 increasing the praseodymium content, and this is also an evidence of 308 praseodymium introduction within the fluorite lattice of ceria (Figure 4).

The weak peak at $1170 \mathrm{~cm}^{-1}$, which is not observed in all catalysts, has 310 been related to surface oxygen groups [19] and several interpretations have 311 been proposed for peaks around $200 \mathrm{~cm}^{-1}$ and $570 \mathrm{~cm}^{-1}[6,14,15,19-22]$. 312 Some authors have assigned peaks at ca. 195 and $570 \mathrm{~cm}^{-1}$ to $\mathrm{RhO}_{x}$ species 313 [20-22] and others attributed these bands to the formation of $\mathrm{Ce}_{y} \mathrm{Pr}_{1-y} \mathrm{O}_{2}$ solid 314 solutions, because a physical mixture of the pure cerium and praseodymium 315 oxides did not show these features [19]. Going into more detail, these bands at 
316195 and $570 \mathrm{~cm}^{-1}$ have been assigned to oxygen vacancies, which affect the 317 asymmetric vibration of the oxide anions $[14,19]$.

318 The relative intensity of the $570 \mathrm{~cm}^{-1}$ band increases with regard to the 319 intensity of the main $\mathrm{F}_{2 \mathrm{~g}}$ mode at $444-463 \mathrm{~cm}^{-1}$ by increasing the praseodymium 320 content (see Figure $4 \mathrm{~b}$ and $4 \mathrm{c}$ ), and the creation of vacant sites on ceria by 321 praseodymium doping is an evidence of solid solution formation [19].

322 3.4. Catalysts characterization TEM, XPS and $\mathrm{H}_{2}$-TPR.

The results obtained by TEM, XPS and $\mathrm{H}_{2}$-TPR, presented and 324 discussed in this section, provide (not only but mainly for the purposes of the 325 current study) information about the $\mathrm{RhO}_{\mathrm{x}}$ particles and their interaction with the 326 ceria-based supports.

TEM images of selected catalysts are included in Figure 5. All the 328 micrographs show ceria crystals and the crystalline planes are even identified in 329 some of them. The size of the ceria-based crystals seems to be consistent with 330 the BET areas of the catalysts included in Table 2, that is, the size of the ceria331 based crystals observed by TEM for $\mathrm{RhO}_{x}\left(\mathrm{H}_{2} \mathrm{O}\right) / \mathrm{CeO}_{2}$ and $332 \mathrm{RhO}_{x}\left(\mathrm{H}_{2} \mathrm{O}\right) / \mathrm{Ce}_{0.9} \mathrm{Pr}_{0.1} \mathrm{O}_{2}\left(60\right.$ and $50 \mathrm{~m}^{2} / \mathrm{g}$, respectively) are smaller than those of $\mathrm{RhO}_{\times}\left(\mathrm{H}_{2} \mathrm{O}\right) / \mathrm{Ce}_{0.5} \mathrm{Pr}_{0.5} \mathrm{O}_{2}$, $\mathrm{RhO}_{x}($ acetone $) / \mathrm{Ce}_{0.9} \mathrm{Pr}_{0.1} \mathrm{O}_{2}$ and

$334 \mathrm{RhO}_{\mathrm{x}}$ (acetone $) / \mathrm{Ce}_{0.5} \mathrm{Pr}_{0.5} \mathrm{O}_{2}\left(20,33\right.$ and $18 \mathrm{~m}^{2} / \mathrm{g}$, respectively). The ceria 335 particles size observed by TEM also correlates with the crystal sizes obtained 336 by XRD (see Table 2).

Small dark spots (marked with red circles) corresponding to $\mathrm{RhO}_{\mathrm{x}}$ nanoparticles are observed in all TEM images as well. The size of these $\mathrm{RhO}_{x}$ 
339 particles is smaller than $2 \mathrm{~nm}$ in most cases. However, a deeper TEM analysis

340 of these catalysts, and of some others of similar composition previously studied

341 [8], confirmed the presence of very small $\mathrm{RhO}_{x}$ particles (even smaller than 1

$342 \mathrm{~nm}$ ) that can be hardly observed with the magnification used to take the images

343 in Figure 5.

The EDS local analysis of the area of the TEM images and the global

345 analysis of the catalysts by FRX confirmed that the amount of rhodium is similar

346 in all catalysts, and therefore, the amount of $\mathrm{RhO}_{\mathrm{x}}$ particles of ca. $2 \mathrm{~nm}$

347 observed in the TEM images of Figure 5 can be related with $\mathrm{RhO}_{x}$ dispersion. If

$348 \mathrm{RhO}_{\mathrm{x}}$ is highly dispersed only few $\mathrm{RhO}_{\mathrm{x}}$ particles are observed in the TEM

349 images, because most $\mathrm{RhO}_{x}$ particles are below the detection limit of the

350 technique. On the contrary, a lot of $\mathrm{RhO}_{x}$ spots are observed in a TEM image

351 when $\mathrm{RhO}_{x}$ is less dispersed.

Comparing the three TEM images (Figure 5) of catalysts prepared by water impregnation of rhodium nitrate, it is observed that there are much more

$354 \mathrm{RhO}_{x}$ particles on the catalyst with $\mathrm{Ce}_{0.5} \mathrm{Pr}_{0.5} \mathrm{O}_{2}$ support than on those with $355 \mathrm{Ce}_{0.9} \mathrm{Pr}_{0.1} \mathrm{O}_{2}$ or $\mathrm{CeO}_{2}$, and this is an evidence of the worst $\mathrm{RhO}_{x}$ dispersion over $356 \mathrm{Ce}_{0.5} \mathrm{Pr}_{0.5} \mathrm{O}_{2}$. This lower $\mathrm{RhO}_{x}$ dispersion on $\mathrm{RhO}_{x}\left(\mathrm{H}_{2} \mathrm{O}\right) / \mathrm{Ce}_{0.5} \operatorname{Pr}_{0.5} \mathrm{O}_{2}$ is 357 coincident with the lowest BET area of this catalyst (see data in Table 2). On 358 the other hand, more $\mathrm{RhO}_{\mathrm{x}}$ particles are observed on $359 \mathrm{RhO}_{x}($ acetone $) / \mathrm{Ce}_{0.9} \mathrm{Pr}_{0.1} \mathrm{O}_{2}$ than on $\mathrm{RhO}_{x}\left(\mathrm{H}_{2} \mathrm{O}\right) / \mathrm{Ce}_{0.9} \mathrm{Pr}_{0.1} \mathrm{O}_{2}$, which could be 360 related with the BET area values (60 and $33 \mathrm{~m}^{2} / \mathrm{g}$, respectively). 
$363 \mathrm{RhO}_{\mathrm{x}}$ dispersion. As a general trend, $\mathrm{RhO}_{x}$ dispersion on $\mathrm{CeO}_{2}$ and $\mathrm{Ce}_{0.9} \mathrm{Pr}_{0.1} \mathrm{O}_{2}$ 364 is better than on $\mathrm{Ce}_{0.5} \mathrm{Pr}_{0.5} \mathrm{O}_{2}$, and $\mathrm{RhO}_{x}$ dispersion is better for water365 impregnated catalysts than for ethanol or acetone-impregnated catalysts. Some 366 of these conclusions are supported by the XPS characterization.

Figure 6 shows the Rh $3 d$ photoelectron spectra of all catalysts. Two 368 peaks are observed in all spectra, corresponding to the $3 d_{5 / 2}$ and $3 d_{3 / 2}$ 369 transitions (around 309 and $313 \mathrm{eV}$, respectively). Both peaks provide similar 370 information about the oxidation state of rhodium. The position of the $R h 3 d_{5 / 2}$ 371 peaks is $309.0-310.0 \mathrm{eV}$ for all catalysts, which corresponds to $\mathrm{Rh}^{3+}$ cations. As 372 reported in the literature, the $\mathrm{Rh} 3 \mathrm{~d}_{5 / 2}$ peak appears at $307.0-307.5 \mathrm{eV}$ for $\mathrm{Rh}^{0}$, 373 at about $308 \mathrm{eV}$ for $\mathrm{Rh}^{+}$, and from 308.3 to $310.5 \mathrm{eV}$ for $\mathrm{Rh}^{3+}$ [23-25].

3756 that deserve a detailed analysis. In $\mathrm{RhO}_{x}$-ceria catalysts, there is a negative 376 charge density transfer from the noble metal to the ceria support, and the extent 377 of such transfer affects the position of the Rh $3 d$ peaks.

The position of the $3 \mathrm{~d}_{5 / 2}$ peak is $309.5 \mathrm{eV}$ for all $\mathrm{RhO}_{x} / \mathrm{CeO}_{2}$ catalysts 379 (Figure 6.a), regardless the solvent used for rhodium impregnation, while it is 380 shifted to slightly higher values for $\mathrm{RhO}_{x} / \mathrm{Ce}_{0.9} \mathrm{Pr}_{0.1} \mathrm{O}_{2}$ catalysts (Figures 6.b) and 381 to lower values for $\mathrm{RhO}_{x} / \mathrm{Ce}_{0.5} \mathrm{Pr}_{0.5} \mathrm{O}_{2}$ (Figures 6.c). This means that the $\mathrm{RhO}_{\mathrm{x}^{-}}$ 382 support interaction strongly depends on the support nature, and ceria doping 383 with $10 \%$ praseodymium favors the $\mathrm{RhO}_{x}$-support interaction while $50 \%$ 384 praseodymium doping hinders the interaction. This is consistent with the lowest 385 BET area of this support (see Table 2). The reason of the positive effect of $10 \%$ 386 praseodymium doping while negative of $50 \%$ praseodymium doping seems to 
387 be that cerium is the main responsible of the charge density transfer from $\mathrm{Rh}$ (III)

388 to the support while praseodymium modifies the cerium behavior. Both cerium 389 and praseodymium can adopt the $3+$ and $4+$ oxidation states, but 390 praseodymium is more prone to form the +3 cation (see Table 3 and discussion 391 below). It is expected that the charge density transfer from $\mathrm{Rh}^{3+}$ to the support 392 occurs with $(\mathrm{Ce}$ and $\mathrm{Pr}) 4+$ cations rather than with +3 cations, and therefore, 393 cerium should interact more efficiently with rhodium than praseodymium. Few 394 praseodymium doping (10\%) has a positive effect because promotes the 395 interaction of $\mathrm{Ce}^{4+}$ cations with rhodium, that is, the presence of $\mathrm{Pr}$ favors the 396 formation of vacant sites on the support and improves oxygen mobility, and this 397 favors the charge density transfer (oxide anions at the end) from rhodium to 398 ceria. $50 \%$ praseodymium doping also has this positive effect, but due to the 399 high diluting effect there is less cerium available to interact with rhodium. The cerium and praseodymium oxidation states have been estimated by 401 XPS, and the values obtained are compiled in Table 3 together with the Ce/Pr 402 surface ratios. The $\mathrm{Ce}^{3+}$ percentage (with regard to total surface cerium) was 403 estimated following the method proposed elsewhere [6] and the $\mathrm{Pr}^{3+}$ percentage 404 (with regard to total surface praseodymium) by using the semi-quantitative 405 method proposed by Borchert et al. [26]. The percentage of $\mathrm{Ce}^{3+}$ is similar for 406 all catalysts prepared with the pure ceria support (34-37\%) and these 407 percentages slightly decrease upon praseodymium doping, evidencing the 408 insertion of the dopant into the ceria lattice. The $\mathrm{Pr}^{3+}$ percentages are much 409 higher than those of $\mathrm{Ce}^{3+}$ due to the easier reducibility of $\mathrm{Pr}^{4+}$ with regard to $410 \mathrm{Ce}^{4+}$. Moreover, the presence of $\mathrm{Pr}^{3+}$ cations partially decreases the reduction 411 of $\mathrm{Ce}^{4+}$. 
Regarding the $\mathrm{Ce} / \mathrm{Pr}$ ratios, they are well below the expected nominal

413 ratios deduced from the stoichiometric formula of the mixed oxides (9 for

$414 \mathrm{Ce}_{0.9} \operatorname{Pr}_{0.1} \mathrm{O}_{2}$ and 1 for $\mathrm{Ce}_{0.5} \operatorname{Pr}_{0.5} \mathrm{O}_{2}$ ). Rodríguez-Luque et al. [27] reported the 415 rhodium nanocrystallites decoration by patches of support in

416 Rhodium/ $\mathrm{Ce}_{\mathrm{y}} \mathrm{Pr}_{1-\mathrm{y}} \mathrm{O}_{2}$ catalysts. It was argued that, during rhodium impregnation,

417 the acid character of the rhodium solution promotes $\mathrm{Pr}^{3+}$ leaching, and after 418 catalyst drying and calcination, such species are accumulated on the particles 419 surface. This would explain the preferential accumulation of praseodymium on 420 the surface of our catalysts.

As a summary, the XPS analysis suggests that praseodymium is partially 422 inserted into the ceria lattice for catalysts with doped ceria supports, but with an 423 enrichment of praseodymium on the particles surface. Such praseodymium 424 doping affects the $\mathrm{RhO}_{\mathrm{x}}$-support interaction, being improved for $10 \%$ 425 praseodymium doping but hindered for $50 \%$ doping.

The $\mathrm{RhO}_{\mathrm{x}}$-support interaction is known to affect the $\mathrm{RhO}_{\mathrm{x}} /$ ceria catalysts

427 reducibility, which is closely related to the catalytic activity for $\mathrm{N}_{2} \mathrm{O}$ 428 decomposition. In order to study such reducibility, $\mathrm{H}_{2}$-TPR experiments were 429 performed and the profiles obtained are compiled in Figure 7.

Three peaks are shown in most $\mathrm{H}_{2}$-reduction profiles, as expected [5, 431 28]. The lowest-temperature peak can be attributed to the reduction of $\mathrm{RhO}_{\mathrm{x}}$, 432 and, in some cases, also to the rhodium-catalyzed ceria-based support surface 433 reduction. The intermediate-temperature peak is attributed by some authors to 434 surface ceria reduction as well, but not catalyzed by the noble metal, whereas 435 other authors relate this peak to surface and/or bulk carbonates decomposition 
436 [29] and/or to surface hydroxyls, peroxides or superoxides reduction. Finally, 437 the peak at highest temperature is attributed to bulk ceria-support reduction. Special attention must be paid to the lowest temperature reduction peak 439 [6], mainly taking into account the symmetry of the peak. The catalysts with high 440 activity for $\mathrm{N}_{2} \mathrm{O}$ decomposition, which are those prepared with the pure ceria 441 support and those impregnated with a water solution of rhodium, regardless the 442 support (see Figure 2), present a single low-temperature $\mathrm{H}_{2}$ reduction peak. On 443 the contrary, two overlapped peaks are evident in catalysts with lower activity, 444 which are those impregnated with acetone or ethanol solutions in doped ceria 445 supports $[6,7]$.

The presence of double-peaks or pronounced shoulders in the lowest 447 temperature $\mathrm{H}_{2}$ reduction peaks occur because $\mathrm{Rh}^{3+}, \mathrm{Pr}^{4+}$ and $\mathrm{Ce}^{4+}$ are reduced 448 sequentially, while symmetric peaks are obtained if such reductions occur 449 simultaneously [7]. Therefore, the shape of this peak is related with the $\mathrm{RhO}_{\mathrm{x}^{-}}$ 450 support interaction and with the formation of doped ceria solid solutions. The 451 catalysts with good $\mathrm{RhO}_{\mathrm{x}}$-support interaction present high catalytic activity [5]. It 452 has been reported that the most active sites for $\mathrm{N}_{2} \mathrm{O}$ decomposition are located 453 at the $\mathrm{RhO}_{x}$-ceria interface [30]. Also, a very effective $\mathrm{N}_{2} \mathrm{O}$ decomposition has 454 been demonstrated to occur on $\mathrm{RhO}_{x} /$ ceria catalysts, and a synergy between 455 rhodium and ceria catalytic sites was proposed. This effective mechanism needs a good $\mathrm{RhO}_{x}$-ceria interaction [17].

The highest temperature peak attributed to bulk reduction disappeared 458 by increasing the amount of praseodymium. This is due to the improved 
459 reducibility with regard to pure ceria, which is related to the enhanced oxygen 460 mobility into the lattice [6].

In conclusion, the activity for $\mathrm{N}_{2} \mathrm{O}$ decomposition of the catalysts studied 462 is related with the $\mathrm{RhO}_{\mathrm{x}}$-support interaction. Both the nature of the ceria support 463 and the solvent used for rhodium precursor impregnation affect such interaction.

464 Ceria doping with $10 \%$ praseodymium has a positive effect on such interaction 465 (see XPS results; Figure 6) and on the catalytic activity (see Figure 2 and Table 466 1), but the benefit on the catalytic activity is only obtained using a water solution 467 for impregnation. On the contrary, when $\mathrm{Ce}_{0.9} \mathrm{Pr}_{0.1} \mathrm{O}_{2}$ is impregnated with 468 ethanol or acetone solutions of rhodium, the temperature gradients created 469 during calcination (Figure 1) promote the support (see BET areas in Table 2) 470 and $\mathrm{RhO}_{x}$ sintering (see $\mathrm{RhO}_{x}$ sizes on TEM images; Figure 5), hindering the $471 \mathrm{RhO}_{\mathrm{x}}-\mathrm{Ce}_{0.9} \mathrm{Pr}_{0.1} \mathrm{O}_{2}$ interaction. The interaction between $\mathrm{RhO}_{\mathrm{x}}$ and $\mathrm{Ce}_{0.5} \mathrm{Pr}_{0.5} \mathrm{O}_{2}$ is 472 not as good as that with $\mathrm{Ce}_{0.9} \mathrm{Pr}_{0.1} \mathrm{O}_{2}$ (see the XPS binding energies of $\mathrm{Rh}^{3+}$ 473 (Figure 6)), but it seems to be enough to keep a high catalytic activity if the 474 impregnation is carried out with a water solution. In fact, the $\mathrm{H}_{2}$-TPR peak at low 475 temperature (Figure 7.c) demonstrates a considerable $\mathrm{RhO}_{\mathrm{x}}$-support interaction. 476 However, acetone or ethanol impregnation also leads to an important decrease 477 in activity, and this must be attributed to a worst $\mathrm{RhO}_{\mathrm{x}}$-support interaction. 478 Finally, pure $\mathrm{CeO}_{2}$ is more stable towards sintering than doped ceria under the 479 calcination conditions of this study (contrary to the phenomenon observed at 480 high-temperature calcination).Pure ceria does not sinter regardless the solvent 481 used for rhodium impregnation, and for this reason all the $\mathrm{RhO}_{\mathrm{x}} / \mathrm{CeO}_{2}$ catalysts 482 kept the same activity. 
This study suggests that the best catalyst is obtained by impregnating

$484 \mathrm{Ce}_{0.9} \mathrm{Pr}_{0.1} \mathrm{O}_{2}$ with a water solution of rhodium precursor. However, if acetone or 485 ethanol must be used for any reason (to improve wettability of a honeycomb 486 monolith channels, for instance) the pure ceria support is more suitable.

\section{Conclusions.}

The effect of the solvent (water, ethanol or acetone) used to impregnate $489 \mathrm{Ce}_{y} \mathrm{Pr}_{1-\mathrm{y}} \mathrm{O}_{2}(\mathrm{y}=1,0.9$ or 0.5$)$ supports with rhodium nitrate, in order to prepare $490 \mathrm{~N}_{2} \mathrm{O}$ decomposition catalysts, have been studied and the following main 491 conclusions can be summarized:

Both the nature of the ceria support and the solvent used for rhodium precursor impregnation affect the $\mathrm{RhO}_{\mathrm{x}}$-support interaction and the activity for $\mathrm{N}_{2} \mathrm{O}$ decomposition.

The use of ethanol or acetone as solvent has a very negative effect on $\mathrm{Ce}_{0.9} \mathrm{Pr}_{0.1} \mathrm{O}_{2}$ and $\mathrm{Ce}_{0.5} \mathrm{Pr}_{0.5} \mathrm{O}_{2}$-containing catalysts, due to the sintering of both the support and $\mathrm{RhO}_{x}$ particles. This affects negatively the $\mathrm{RhO}_{x^{-}}$ support interaction which directly hinders the catalytic activity for $\mathrm{N}_{2} \mathrm{O}$ decomposition. This negative effect is due to the rhodium-catalyzed solvent combustion.

Ceria doping with $10 \%$ praseodymium has a positive effect on the $\mathrm{RhO}_{x^{-}}$ support interaction (and on the catalytic activity), which is observed as a negative charge density transfer from the noble metal to the ceria support (only obtained using water for impregnation). 
The interaction between $\mathrm{RhO}_{\mathrm{x}}$ and $\mathrm{Ce}_{0.5} \mathrm{Pr}_{0.5} \mathrm{O}_{2}$ is not as good as that with $\mathrm{Ce}_{0.9} \mathrm{Pr}_{0.1} \mathrm{O}_{2}$, but it is enough to keep a high catalytic activity if rhodium is impregnated with a water solution. However, acetone or ethanol impregnation leads to an important decrease in activity, and this must be attributed to the worst interaction of $\mathrm{RhO}_{x}$ with the support, as deduced from the shape of the lowest temperature $\mathrm{H}_{2}$-TPR peaks.

511

\section{Acknowledgments}

513

The authors thank the financial support of Generalitat Valenciana

514 (Project Prometeo 2009/047), the Spanish Ministry of Economy and

515 Competitiveness (Project CTQ2012-30703), and the UE FEDER funding. 
518 [1] A. Trovarelli, Catal. Rev. Sci. Eng. 38 (1996) 439.

519 [2] A. Trovarelli, C. De Leitenburg, M. Boaro, G. Dolcetti, Catal. Today 50 520

521

522

523

524

525

526

527

528

529

530

[3] M. Shelef, G. W. Graham, R. W. McCabe, in: A. Trovarelli (ed), Catalysis by ceria and related materials Catalytic Science Series. Vol. 2, Imperial College Press,2002, pp 343-376.

[4] J. Kašpar, P. Fornasiero, N. Hickey, Catalysis Today 77 (2003) 419.

[5] S. Imamura, J. Tadani, Y. Saito, Y. Okamoto, H. Jindai, C. Kaito, Appl. Catal. A 201 (2000) 121.

[6] A. Bueno-López, I. Such-Basáñez, C. Salinas-Martínez de Lecea, J. Catal. 244 (2006) 102.

[7] V. Rico-Pérez, S. Parres-Esclapez, M.J. Illán-Gómez, C. SalinasMartínez de Lecea, A. Bueno-López, Appl. Catal. B 107 (2011) 18.

531

532

[8] V. Rico-Pérez, M.A. Velasco-Beltrán, Q. He, Q. Wang, C. SalinasMartínez de Lecea, A. Bueno-López, Catal. Commun. 33 (2013) 47.

533

534

[9] J. Roggenbuck, T. Waitz, M. Tiemann, Micropor. Mesopor. Mat. 113 (2008) 575.

535

536

[10] T.A. Nijhuis, A.E.W. Beers, T. Vergunst, I. Hoek, F. Kapteijn, J.A. Moulijn, Cat. Rev. Sci. Eng. 43 (2001) 345.

537

538

539

540

541

542

543

544

545

[11] L. C. Almeida, F. J. Echave, O. Sanz, M. A. Centeno, J. A. Odriozola, M. Montes. Stud. Surf. Sci. Catal. 175 (2010) 25.

[12] C. Bueno-Ferrer, S. Parres-Esclapez, D. Lozano-Castelló, A. BuenoLópez. J. Rare Earths 28 (2010) 647.

[13] H. He, H.X. Dai, C.T. Au, Catal. Today 90 (2004) 245.

[14] J.R. McBride, K.C. Hass, B.D. Poindexter, W.H. Weber, J. Appl. Phys. 76 (1994) 2435.

[15] S. Bernal, G. Blanco, M.A. Cauqui, A. Martin, J.M. Pintado, A. Galtayries, R. Sporken, Surf. Int. Anal. 30 (2000) 85.

[16] K. Aboussaid, S. Bernal, G. Blanco, J. J. Calvino, G. A. Cifredo, M. Lopez-Haro, J. M. Pintado, M. S. el Begrani, O. Stephan, S. Trasobares, Surf. Int. Anal. 40 (2008) 242. 
[17] S. Parres-Esclapez, I. Such-Basáñez, M.J. Illán-Gómez, C. SalinasMartínez de Lecea, A. Bueno-López, J. Catal. 276 (2010) 390.

[18] M. Yashima, H. Arashi, M. Kakihana, M. Yoshimura, J. Americ. Ceram. 553

554

555

556

557

558

559

560 [23] http://www.lasurface.com. Access May 2013

561

562

563

564

565

566

567

568

569

570

571

572

573

574

575

576

[24] X.D. Wu, L.H. Xu, D. Weng, Appl. Surf. Sci. 221 (2004) 375.

[25] J. Soria, A. Martínez-Arias, J.L.G. Fierro, J.C. Conesa, Vacuum 46 (1995) 1201.

[26] H. Borchert, Y.V. Frolova, V.V. Kaichev, I.P. Prosvirin, G.M. Alikina, A.I. Lukashevich, V.I. Zaikovskii, E.M. Moroz, S.N. Trukhan, V.P. Ivanov, E.A. Paukshtis, V.I. Bukhtiyarov, V.A. Sadykov, J. Phys. Chem. B 109 (2005) 5728.

[27] M.P. Rodríguez-Luque, J.C. Hernandez, M.P. Yeste, S. Bernal, M.A. Cauqui, J.M. Pintado, J.A. Perez-Omil, O. Stephan, J.J. Calvino, S. Trasobares. J. Phys. Chem. C 112 (2008) 5900.

[28] P. Fornasiero, P. Di Monte, G.R. Rao, J. Kaspar, S. Meriani, A. Trovarelli, M. Graziani, J. Catal. 151 (1995) 168.

[29] F.M.Z. Zotin, L. Tournayan, J. Varloud, V. Perrichon, R. Frety, Appl. Catal. A 98 (1993) 99.

[30] J. Cunningham, J.N. Hickey, R. Cataluna, J.C. Conesa, J. Soria, A. Martínez-Arias. Stud. Surf. Sci. Catal. 101 (1996) 681. 
Table 1. Temperature required to decompose $50 \%$ of $\mathrm{N}_{2} \mathrm{O}\left(T_{50}\right)$ in the catalytic tests.

\begin{tabular}{lc}
\hline Catalyst & $\mathrm{T}_{\mathbf{5 0}}$ (ㅇ) \\
\hline $\mathrm{RhO}_{\mathbf{x}}\left(\mathrm{H}_{2} \mathrm{O}\right) / \mathrm{CeO}_{2}$ & 252 \\
$\mathrm{RhO}_{x}($ ethanol $) / \mathrm{CeO}_{2}$ & 252 \\
$\mathrm{RhO}_{x}($ acetone $) / \mathrm{CeO}_{2}$ & 252 \\
$\mathrm{RhO}_{\mathbf{x}}\left(\mathrm{H}_{2} \mathrm{O}\right) / \mathrm{Ce}_{0.9} \mathrm{Pr}_{0.1} \mathrm{O}_{2}$ & 242 \\
$\mathrm{RhO}_{x}($ ethanol $) / \mathrm{Ce}_{0.9} \mathrm{Pr}_{0.1} \mathrm{O}_{2}$ & 287 \\
$\mathrm{RhO}_{x}($ acetone $) / \mathrm{Ce}_{0.9} \mathrm{Pr}_{0.1} \mathrm{O}_{2}$ & 301 \\
$\mathrm{RhO}_{x}\left(\mathrm{H}_{2} \mathrm{O}\right) / \mathrm{Ce}_{0.5} \operatorname{Pr}_{0.5} \mathrm{O}_{2}$ & 252 \\
$\mathrm{RhO}_{x}($ ethanol $) / \mathrm{Ce}_{0.5} \operatorname{Pr}_{0.5} \mathrm{O}_{2}$ & 326 \\
$\mathrm{RhO}_{x}($ acetone $) / \mathrm{Ce}_{0.5 \mathrm{Pr}_{0.5} \mathrm{O}_{2}}$ & 319 \\
\hline
\end{tabular}

Table 2. Results of the $\mathrm{N}_{2}$ adsorption and XRD characterization.

\begin{tabular}{|c|c|c|c|}
\hline Sample & $\begin{array}{c}\text { BET } \\
\text { surface } \\
\text { area } \\
\left(\mathrm{m}^{2} / \mathrm{g}\right)\end{array}$ & $\begin{array}{c}\text { Crystal } \\
\text { size } \\
(\mathrm{nm})\end{array}$ & $\begin{array}{l}\text { Lattice } \\
\text { parameter } \\
\text { (nm) }\end{array}$ \\
\hline $\mathrm{CeO}_{2}$ & 61 & - & - \\
\hline $\mathrm{RhO}_{x}\left(\mathrm{H}_{2} \mathrm{O}\right) / \mathrm{CeO}_{2}$ & 60 & 14 & 0.5413 \\
\hline $\mathrm{RhO}_{x}($ ethanol $) / \mathrm{CeO}_{2}$ & 60 & 14 & 0.5412 \\
\hline $\mathrm{RhO}_{x}($ acetone $) / \mathrm{CeO}_{2}$ & 56 & 15 & 0.5412 \\
\hline $\mathrm{Ce}_{0.9} \mathrm{Pr}_{0.1} \mathrm{O}_{2}$ & 50 & - & - \\
\hline $\mathrm{RhO}_{x}\left(\mathrm{H}_{2} \mathrm{O}\right) / \mathrm{Ce}_{0.9} \mathrm{Pr}_{0.1} \mathrm{O}_{2}$ & 50 & 18 & 0.5417 \\
\hline $\mathrm{RhO}_{x}($ ethanol $) / \mathrm{Ce}_{0.9} \operatorname{Pr}_{0.1} \mathrm{O}_{2}$ & 31 & 21 & 0.5416 \\
\hline $\mathrm{RhO}_{x}($ acetone $) / \mathrm{Ce}_{0.9} \mathrm{Pr}_{0.1} \mathrm{O}_{2}$ & 33 & 21 & 0.5415 \\
\hline $\mathrm{Ce}_{0.5} \mathrm{Pr}_{0.5} \mathrm{O}_{2}$ & 18 & - & - \\
\hline $\mathrm{RhO}_{x}\left(\mathrm{H}_{2} \mathrm{O}\right) / \mathrm{Ce}_{0.5} \operatorname{Pr}_{0.5} \mathrm{O}_{2}$ & 20 & 24 & 0.5412 \\
\hline $\mathrm{RhO}_{\times}($ethanol $) / \mathrm{Ce}_{0.5} \mathrm{Pr}_{0.5} \mathrm{O}_{2}$ & 17 & 21 & 0.5420 \\
\hline $\mathrm{RhO}_{\mathrm{x}}($ acetone $) / \mathrm{Ce}_{0.5} \mathrm{Pr}_{0.5} \mathrm{O}_{2}$ & 18 & 21 & 0.5420 \\
\hline
\end{tabular}


Table 3. $\mathrm{Ce}^{3+}$ and $\mathrm{Pr}^{3+}$ percentages (with regard to total $\mathrm{Ce}$ and $\mathrm{Pr}$ surface contents, respectively) and Ce/Pr atomic ratio determined by XPS.

\begin{tabular}{lccc}
\hline & $\mathrm{Ce}^{3+}(\%)$ & $\mathrm{Pr}^{3+}(\%)$ & $\mathrm{Ce} / \mathrm{Pr}$ \\
\hline $\mathrm{RhO}_{\mathbf{x}}\left(\mathrm{H}_{2} \mathrm{O}\right) / \mathrm{CeO}_{2}$ & 37 & - & - \\
$\mathrm{RhO}_{\mathbf{x}}($ ethanol $) / \mathrm{CeO}_{2}$ & 35 & - & - \\
$\mathrm{RhO}_{x}($ acetone $) / \mathrm{CeO}_{2}$ & 34 & - & - \\
$\mathrm{RhO}_{\mathbf{x}}\left(\mathrm{H}_{2} \mathrm{O}\right) / \mathrm{Ce}_{0.9} \mathrm{Pr}_{0.1} \mathrm{O}_{2}$ & 28 & 58 & 4.0 \\
$\mathrm{RhO}_{\mathbf{x}}($ ethanol $) / \mathrm{Ce}_{0.9} \mathrm{Pr}_{0.1} \mathrm{O}_{2}$ & 30 & 72 & 3.4 \\
$\mathrm{RhO}_{\mathbf{x}}($ acetone $) / \mathrm{Ce}_{0.9} \mathrm{Pr}_{0.1} \mathrm{O}_{2}$ & 28 & 66 & 3.7 \\
$\mathrm{RhO}_{\mathbf{x}}\left(\mathrm{H}_{2} \mathrm{O}\right) / \mathrm{Ce}_{0.5} \mathrm{Pr}_{0.5} \mathrm{O}_{2}$ & 31 & 51 & 0.6 \\
$\mathrm{RhO}_{x}($ ethanol $) / \mathrm{Ce}_{0.5} \mathrm{Pr}_{0.5} \mathrm{O}_{2}$ & 30 & 66 & 0.7 \\
$\mathrm{RhO}_{\mathbf{x}}($ acetone $) / \mathrm{Ce}_{0.5} \mathrm{Pr}_{0.5} \mathrm{O}_{2}$ & 30 & 50 & 0.7 \\
\hline
\end{tabular}




\section{Figure captions}

Figure 1. Temperature profiles during the thermal treatment of ceriaimpregnated rhodium precursor (using water, ethanol or acetone as solvent) in test tubes placed in a vertical furnace pre-heated at $250^{\circ} \mathrm{C}$.

Figure 2. $\mathrm{N}_{2} \mathrm{O}$ decomposition as a function of temperature for catalysts supported on: (a) $\mathrm{CeO}_{2}$, (b) $\mathrm{Ce}_{0.9} \mathrm{Pr}_{0.1} \mathrm{O}_{2}$ and (c) $\mathrm{Ce}_{0.5} \mathrm{Pr}_{0.5} \mathrm{O}_{2}$.

Figure 3. X-ray diffractograms of catalysts supported on (a) $\mathrm{CeO}_{2}$, (b) $\mathrm{Ce}_{0.9} \mathrm{Pr}_{0.1} \mathrm{O}_{2}$ and (c) $\mathrm{Ce}_{0.5} \mathrm{Pr}_{0.5} \mathrm{O}_{2}$. Diffractograms 1, 4, 7 correspond to samples impregnated with ethanol solution; 2, 5, 8 to samples impregnated with acetone solution and 3, 6, 9 to samples impregnate with water solution.

Figure 4. Raman spectra of catalysts with RhOx supported on (a) $\mathrm{CeO}_{2}$, (b) $\mathrm{Ce}_{0.9} \mathrm{Pr}_{0.1} \mathrm{O}_{2}$ and (c) $\mathrm{Ce}_{0.5} \mathrm{Pr}_{0.5} \mathrm{O}_{2}$ (c).

Figure 5. TEM images of catalysts (a) $\mathrm{RhO}_{x}\left(\mathrm{H}_{2} \mathrm{O}\right) / \mathrm{CeO}_{2}$, (b)

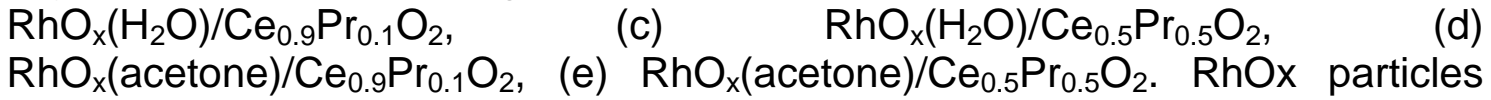
have been circled.

Figure 6. Rh 3d XPS spectra of catalysts with RhOx supported on (a) $\mathrm{CeO}_{2}$, (b) $\mathrm{Ce}_{0.9} \mathrm{Pr}_{0.1} \mathrm{O}_{2}$ and (c) $\mathrm{Ce}_{0.5} \mathrm{Pr}_{0.5} \mathrm{O}_{2}$.

Figure 7. $\mathrm{H}_{2}$-TPR profiles of catalysts with $\mathrm{RhOx}$ supported on (a) $\mathrm{CeO}_{2}$, (b) $\mathrm{Ce}_{0.9} \mathrm{Pr}_{0.1} \mathrm{O}_{2}$ and (c) $\mathrm{Ce}_{0.5} \mathrm{Pr}_{0.5} \mathrm{O}_{2}$. 
Figure 1.

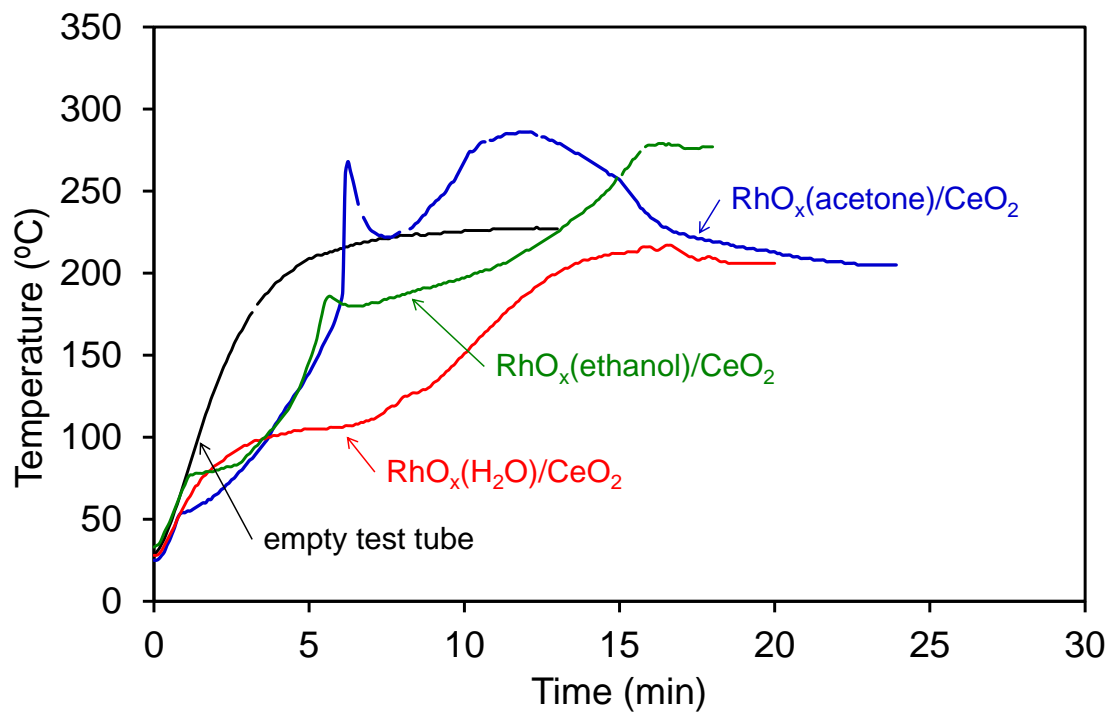


Figure 2.
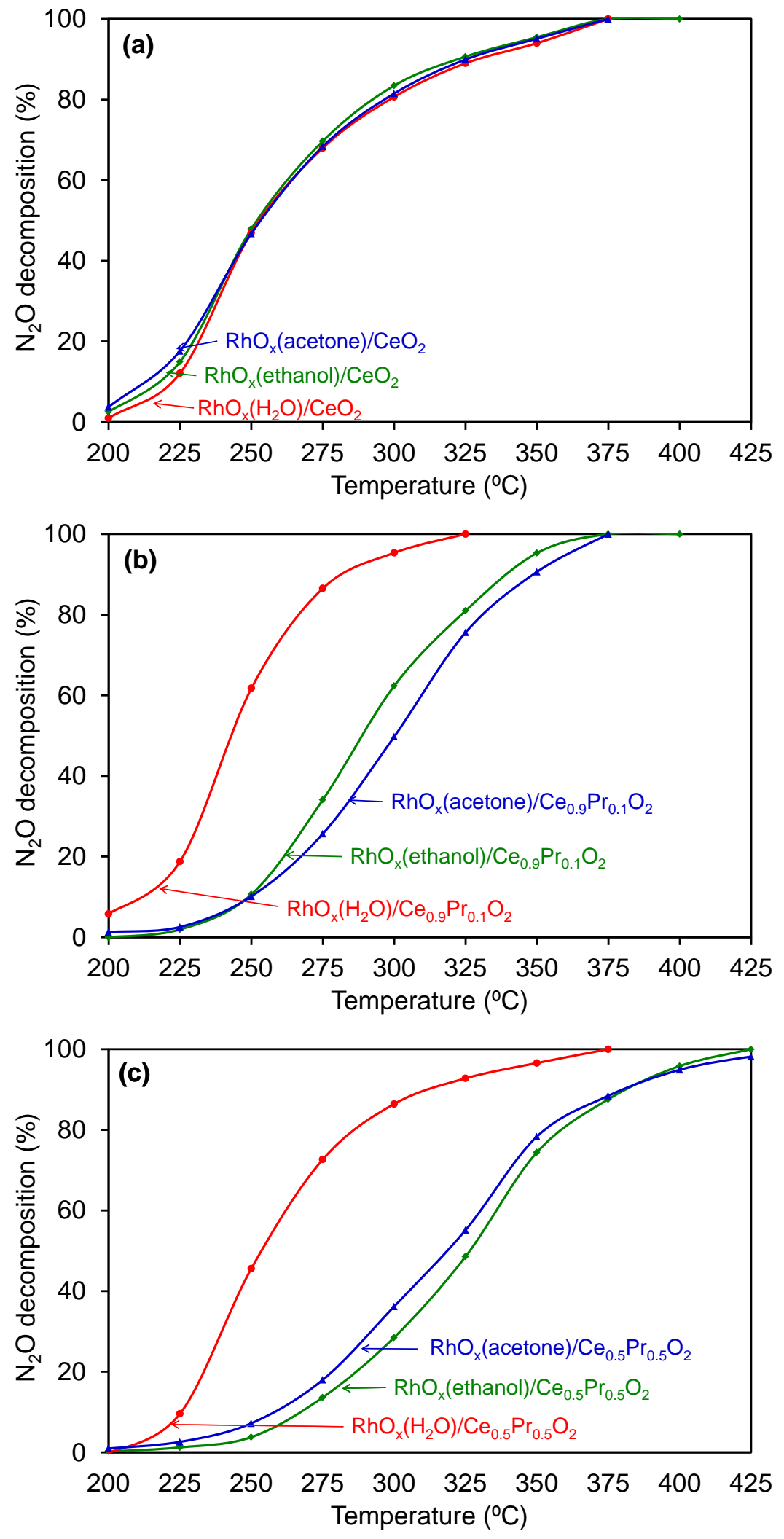
Figure 3.
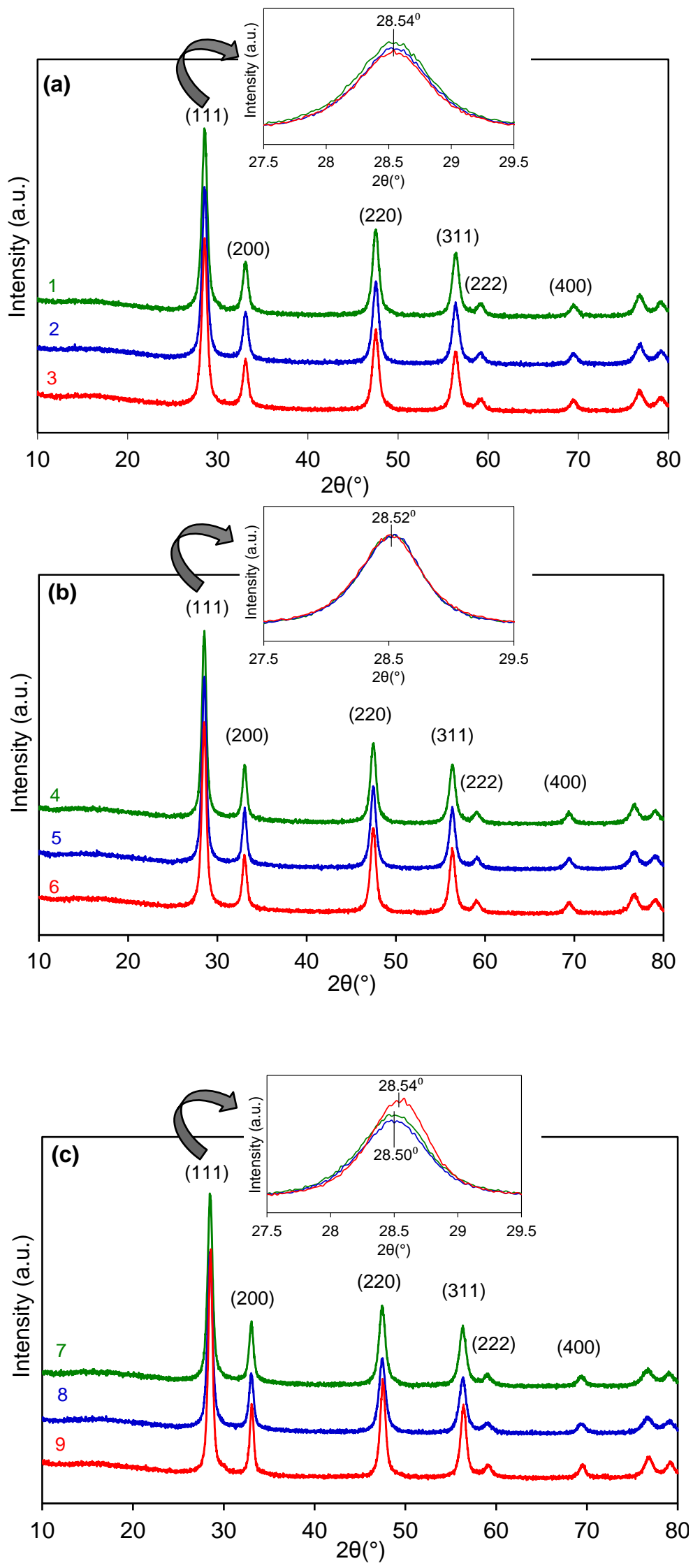
Figure 4.
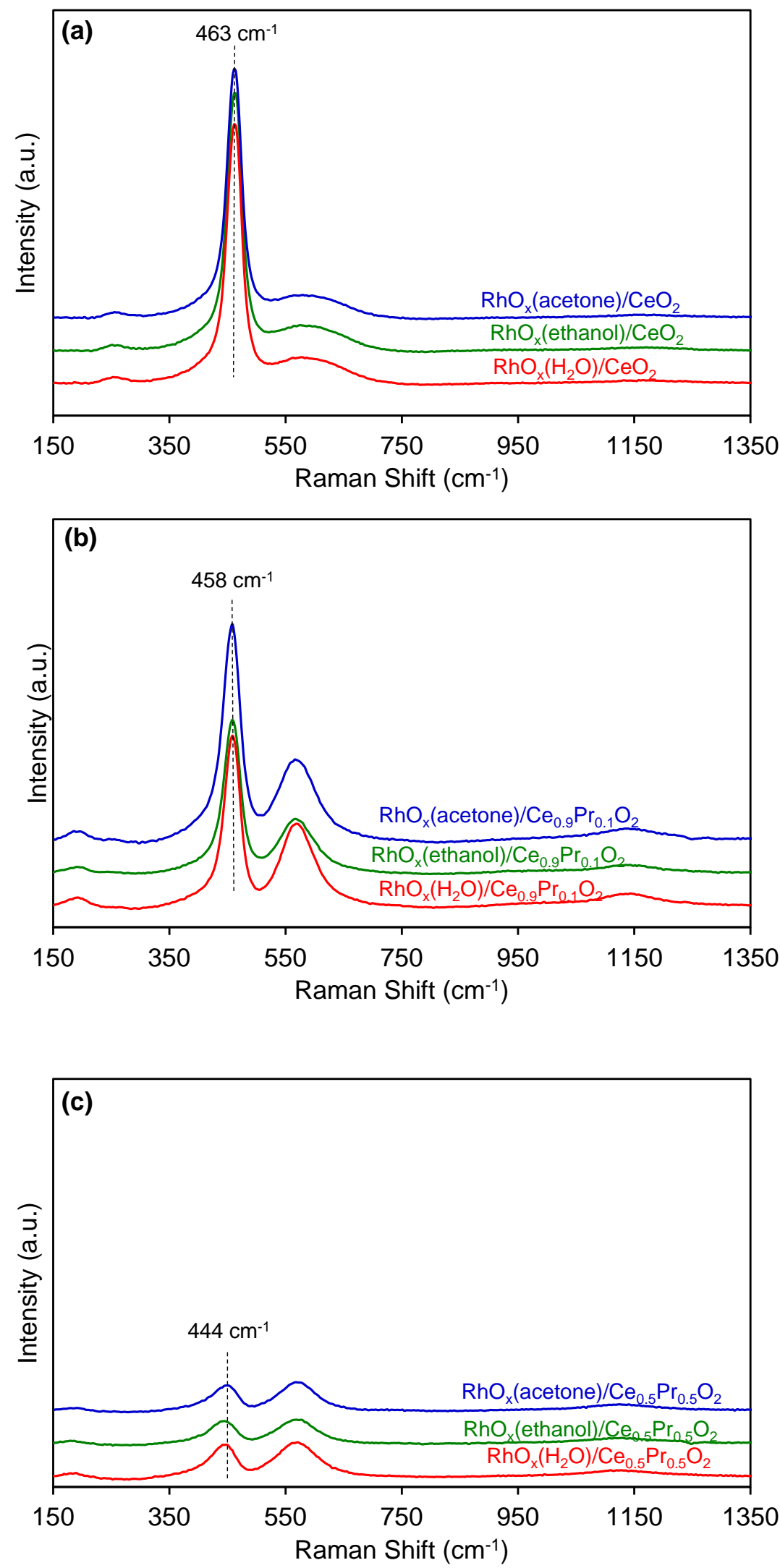
Figure 5.
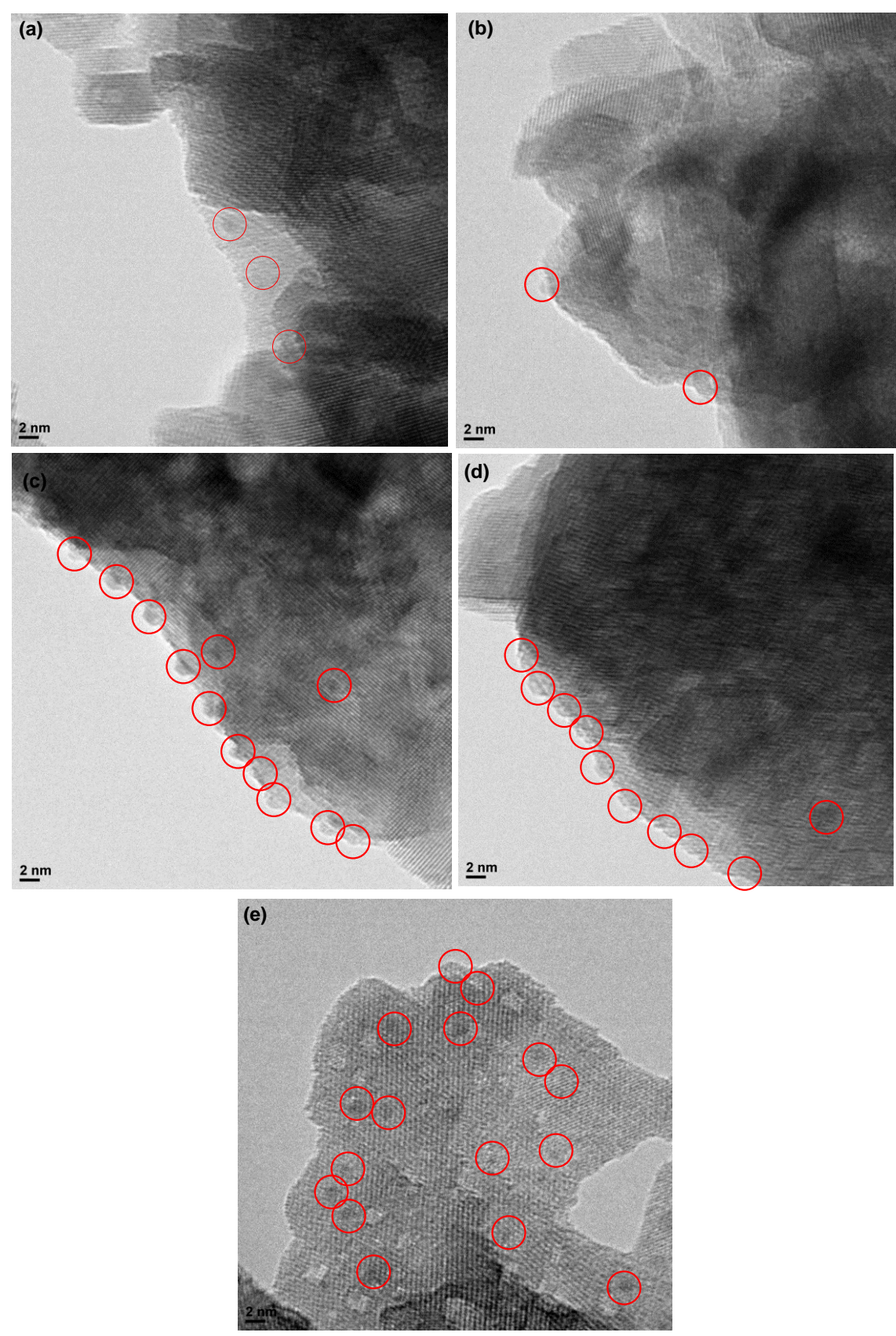
Figure 6.
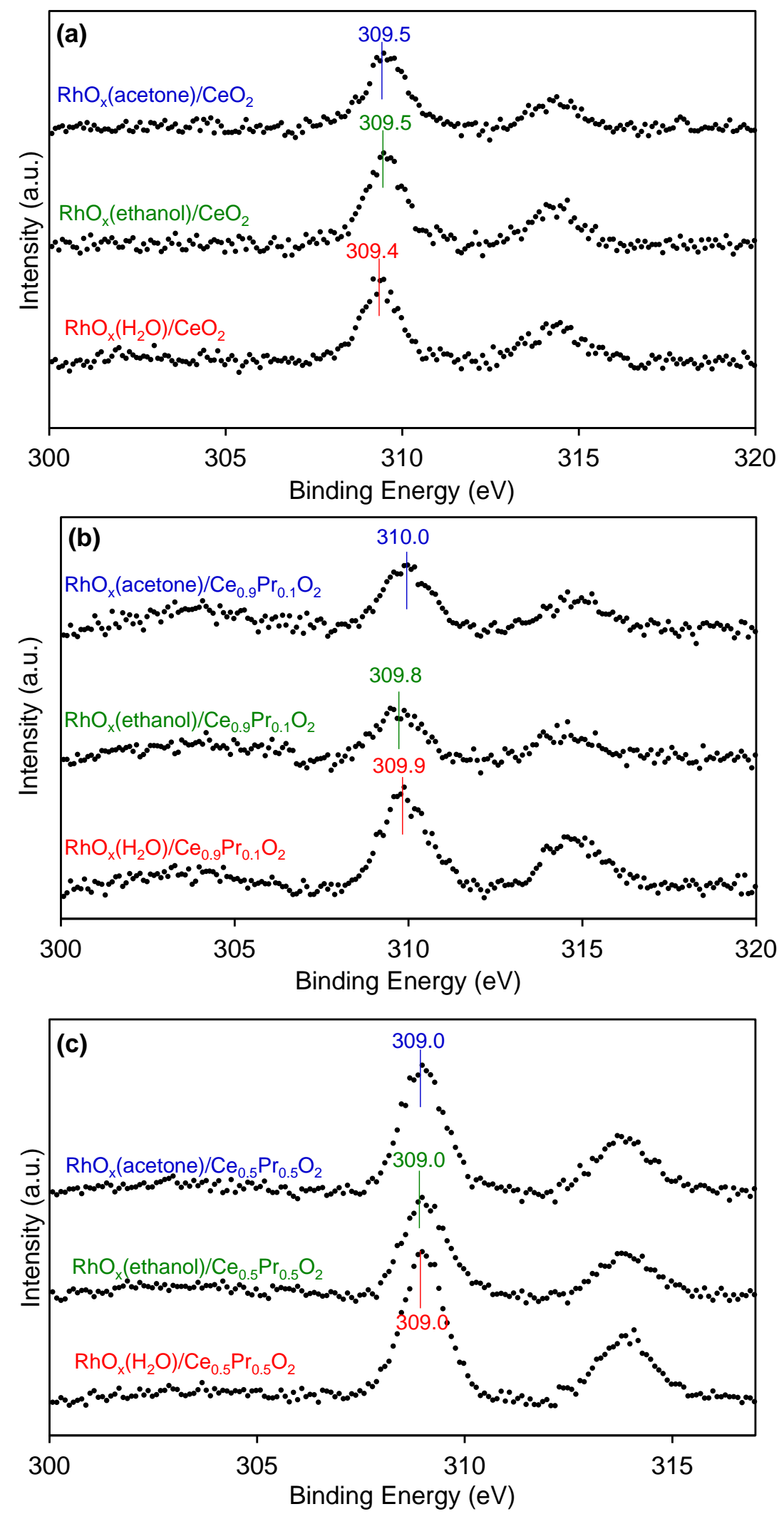
Figure 7.
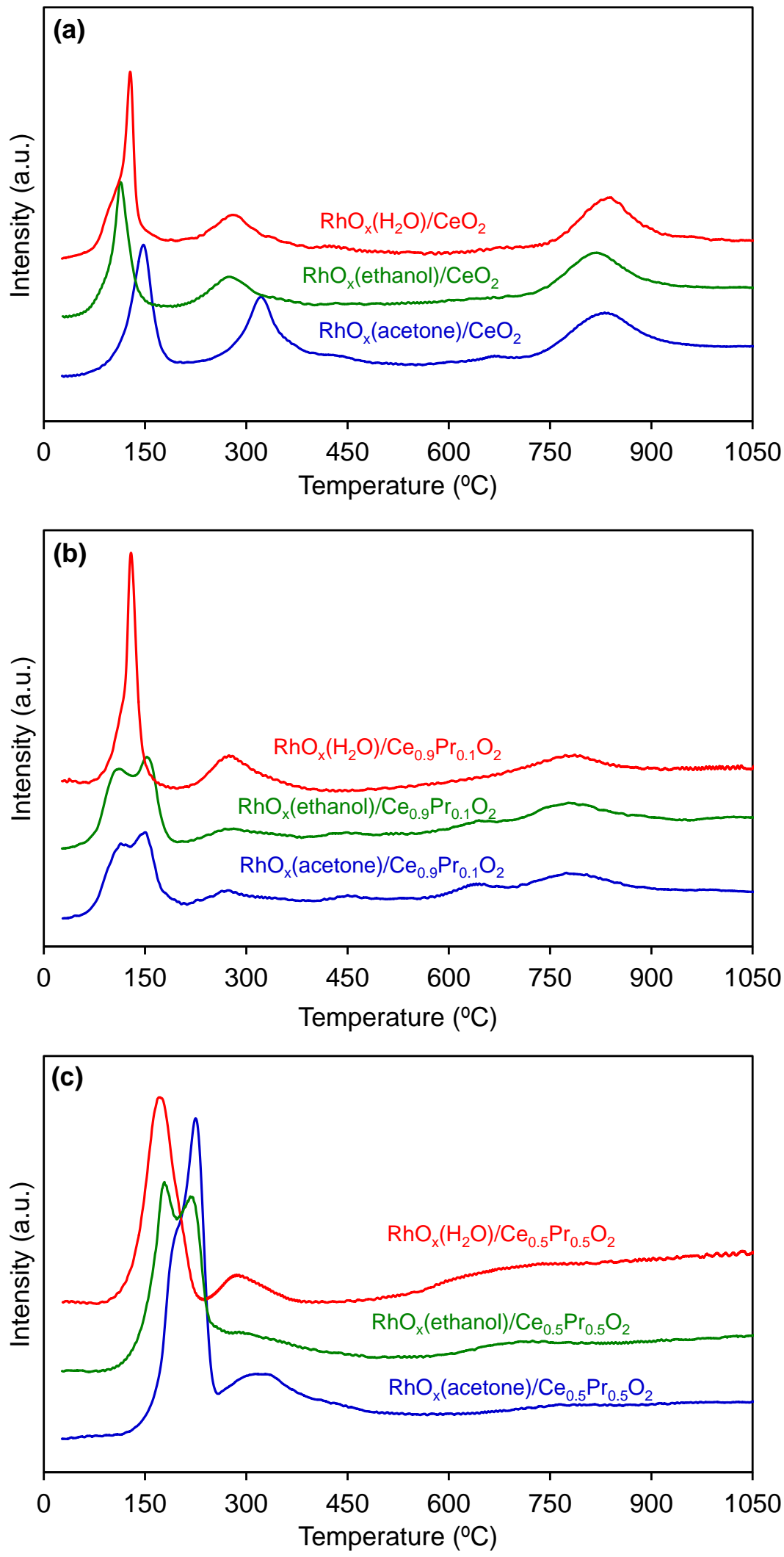